\title{
Attitudes and Knowledge of Bahamian College Students Regarding Sexual Consent
}

\author{
Nicolette Bethel (iD https://orcid.org/0000-0003-1873-3539 \\ Social Sciences \\ William J. Fielding (D) https://orcid.org/0000-0001-5433-9673 \\ Institutional Strengthening \& Accreditation \\ University of The Bahamas
}

https://doi.org/10.15362/ijbs.v26i0.371

\begin{abstract}
The Bahamas is reported to have a high incidence of rape. As lack of consent prior to sexual intercourse is typically associated with sexual abuse or rape, this paper focuses on the provision of consent prior to sexual intercourse arising from the sexual experiences of university students in The Bahamas. This Internet-based study of 621 students $(74.1 \%$ female and $25.4 \%$ male, with $0.5 \%$ indicating that their sex was "other") indicates that-if the legal interpretation of rape is applied to the sexual experiences of study participants - almost half were victims of rape or sexual abuse. None of the males who admitted to being victims of rape reported the event. This suggests that males, as well as many female rape/sexual abuse victims, may never receive the help they need to help them recover from their attack. Female students in The Bahamas who consent to unwanted sexual intercourse appear to have been pressured to a greater extent than their counterparts in North America.
\end{abstract}

\section{Introduction}

Prior consent is considered a key criterion in determining the legality or morality of sexual intercourse between adults. Historically, consent, either of parents of the participants, or the participants themselves, has been required in marriage, irrespective of a contract or other elements (Martos, 2014). Today, it is still agreed that consent remains essential to morally engage in sexual intercourse. The fact that consent can take more than one form can obfuscate the interpretation as to when consent has been given (Husak \& Thomas, 2001). A highprofile court case in Europe in 2019 highlighted that the absence of consent needed to be accompanied by violence for sexual intercourse to be classified as rape (for example, "Five Men Convicted of Sexual Abuse Rather than Gang Rape," 2019), despite the position of international agreements, such as the Istanbul Convention of 2014 and national agencies which emphasise the importance of consent (for example, RAAIN, the Rape, Abuse \& Incest National Network https://www.rainn.org). This makes the study of consent prior to sexual intercourse an important aspect in assessing if sexual encounters result in rape or not.

Many children are at risk of sexual abuse early in life. Reid et al. (2014) have argued that "child sexual abuse (CSA) is prevalent in the Caribbean. In a survey of 15,695 students, 10 to 18 years old, Halcon and colleagues (2003) found that $34.1 \%$ of children in 9 Caribbean countries were sexually active. Of these, $92.3 \%$ first engaged in sexual intercourse before the age of 16 years and $42.8 \%$ before the age of 10 years" (Halcon et 
al., 2003 p. 256). In the Bahamian school population, $9 \%$ of female students have reported to have engaged in sexual intercourse, which could be classified as abuse or rape (Sutton, 2016). The Caribbean is recognised as having one of the highest rates of forced sexual initiation: $47.6 \%$ of females and $31.9 \%$ of males - figures which are high, particularly when compared to South Africa, $28.4 \%$ of females and $6.4 \%$ of males (World Health Organisation, 2002, p. 153). A recent study by The Bahamas Ministry of Health (2019) reported that the mean age of sexual intercourse for the first time was 17 years, $(15.5 \%$ of men and $7.5 \%$ of women had engaged in sexual intercourse by the age of 15 ) and $8.1 \%$ of men and $17.6 \%$ of women had experienced a sexual act against their will. These two last figures suggest that the incidence of sexual rape/abuse could be as high as $23.6 \%$ for men and $25.1 \%$ for women (Bahamas Ministry of Health, 2019, p. 6).

The Bahamas is reported to have one of the highest incidences of rape in the Caribbean region, and its residents have a higher tolerance of gender-based violence than in other parts of the region (Sutton \& Ruprah, 2017). This is despite the number of reported rapes decreasing in recent years (Royal Bahamas Police Force, 2018). The director of The Bahamas Crisis Centre, an organisation which offers support to sexual abuse victims, has claimed that The Bahamas suffers from a rape epidemic (Knowles, 2019). International agencies have also raised concern about the number of reported rapes, and the OECD Development Centre (2019) maintains that The Bahamas has "the highest number of rape cases reported throughout the Caribbean," despite the low numbers of cases reported by the police.

In addition to these debates, the alleged under reporting of sexual offences, and rape in particular, has been raised due to differences in figures produced by The Bahamas Crisis
Centre, The Royal Bahamas Police Force and the Princess Margaret Hospital (Sutton, 2016). Aranha (2016b) suggested that as many as $95 \%$ of child sexual abuse cases in The Bahamas may go underreported. One factor which may contribute to underreporting is the lack of recognition on behalf of victims that they have been subject to rape, as well as the fact that the victimiser is likely to be known to the victim (Sutton, 2016). The alleged underreporting of sexual abuse and rape has occurred at a time when the United Nations remains critical of the treatment of women in The Bahamas (Convention on the Elimination of all forms of Discrimination Against Women, 2018). Unpublished results from a study by Fielding (2019) failed to find an association between differences in feelings of safety among women who had and had not been selfreported victims of sexual abuse. This contrasted with a reduced feeling of safety in males who had been sexually abused. One interpretation suggested was that sexual abuse is normal for women, and so being a victim of sexual abuse would not be detected as a factor which reduced feelings of safety. This is consistent with Curry (2016) who noted the "normalisation of violence against women" (p. 15) in The Bahamas, centred on domestic orientated violence.

Internationally, in various populations, between $14 \%$ to $36 \%$ of females have experienced rape (Wilson \& Scapa, 2015). In a 2015 study of sexual abuse on United States college campuses, $25.9 \%$ of female students reported having non-consensual sex while at university and $23.3 \%$ of females had been forced into having sex through force, lack of consent or being incapacitated, (Cantor et al., 2019). However, simple comparisons with United States colleges may not be an appropriate frame of reference for this study because many U.S. colleges are residential, and so their students, unlike students in The Bahamas, do not typically live in the 
community and home setting, even when they are full-time students. U.S. college students experience less physical violence than their counterparts in The Bahamas (Fielding, Risley-Curtiss, \& Cronin, 2015), so it might be expected that Bahamian students may be at higher risk than U.S. students of sexual abuse if it is assumed that sexual abuse is associated with physical violence. In college student households in The Bahamas, Plumridge and Fielding (2009) showed that homes in which domestic violence occurred also had an elevated risk of also being homes in which sexual abuse occurred.

While rape in particular is associated with females, we note that males can be sexually abused, and their victimisation is of concern (McKeever, 2019). While some countries do not recognise male rape, male rape in The Bahamas, as elsewhere, is likely to be associated with homosexuality and so suffer the stigma associated with that (Sivakumaran, 2005), particularly as homosexual acts are illegal in The Bahamas. This will again have implications for reporting such events, and consequently make it unlikely that victims will access counselling (Riccardi, 2010). This may be even more important in the case of male rape victims than female rape victims (Hovel, 2019).

Two recent public controversies in The Bahamas have focused on gender issues: the debate to outlaw marital rape (Benjamin \& LeGrand, 2012), and the two failed referenda on gender equality (Aranha 2016a, BethellBennett 2016b, Fielding \& Ballance, 2019). In The Bahamas, gender-based attitudes, such as the man is the head of the household, and women should submit to their husbands, are learnt early in life, generally from mothers. Such learning is reinforced by religious leaders and apparently endorsed by elected members of government (Fielding \& Ballance, 2019).
The Sexual Offences Act (1991) makes it clear that consent must be provided by both parties if sexual encounters are not to be deemed abusive. It is illegal for persons under the age of 16 to engage in sexual intercourse. This is commonly referred as statutory rape, as consent is not a consideration. There is a provision for 15year-old married persons to engage in sexual intercourse, but this would apply to very few people, as only about $2 \%$ of Bahamian females aged 18 or under are married (OECD Development Centre, 2019). Under the law, persons aged 16 or over must not only provide consent but must also be in a position to provide consent knowingly and freely. Consequently, consent to sexual acts due to fear of a partner, or being under the influence of drugs or alcohol, would be expected to invalidate any apparent consent.

There is also a less clear-cut aspect of persons giving consent against their will, which may be most relevant to cases of date or acquaintance rape (Mills \& Granoff, 1992). While coercion can result in abuse or rape, where the line is drawn between encouragement and force is not defined in this study; we use the perceptions of participants. The idea of consent itself has resulted in much debate (for example, Little, 2005).

While there has been much reported on risky sexual behaviours of children and adults in The Bahamas, particularly in relation to HIV/AIDS (Deveaux \& Rolle, 2016), the aspect of consent in sexual encounters appears to have received less examination. The purpose of this study was to examine consent prior to sexual intercourse. In particular, the study aimed to determine if participants knew if they were victims of rape. It also sought to examine what linkages may exist between rape/sexual abuse and other factors, such as intimate partner violence (IPV), and age of first sexual intercourse. Identification of any such 
linkages might be useful in influencing interventions which may help reduce the prevalence of unwanted sexual intercourse.

The concept of consent presupposes the idea of an individual as a discrete social being who has the right, among other rights, to determine the ways in which they behave (Brooks, 2020; Ferrarese, 2015; Ferzan, 2018; Gray, 2015). In this study, the specific focus is consent in relation to sexual intercourse. However, it is worth noting briefly the ways in which consent may or may not be exercised in other areas of Bahamian life.

In the Bahamian context, the question of consent has larger implications than the question of the right to agree to sexual intercourse. In a nation with a history of colonization and enslavement (BethellBennett, 2016a, Curry \& Ulentin, 2019) in which women are constitutionally secondclass citizens (Aranha, 2016a), consent also incorporates the ability of the individual Bahamian woman (in particular) to exercise consent or reasonable control over many other aspects of her daily life. Further, because it is a nation in which the needs and well-being of the majority of its residents have customarily been subordinated to the controlling influences of external forces, whether they be the individual tourist or the decrees of international credit rating agencies such as Standard \& Poors or large economic blocs such as the OECD (Hartnell, 2020a, 2020b), Bahamians occupy a social landscape in which the question of consent extends beyond their bodies into every area of experience. Therefore, when examining the question of consent to sexual intercourse, the question can be considered a part of a larger one: how far does the average Bahamian give consent to any activity on a daily basis? While this question is multifaceted and complex, the ability to determine sexual encounters, through consent, is a basic right, and so an important consideration in the wider "control" or "consent" in activities which society participates or is subjected.

This paper attempts to contribute to our understanding as to why rape/sexual abuse is apparently underreported in The Bahamas and so allow victimisers and victims to receive the counselling they require. Further, a better understanding on consent would allow those who provide education in life skills, to better equip young people to protect themselves from abuse. Consequently, this study sought to examine consent, or its lack, prior to sexual intercourse focusing on rape.

Using university based students as participants, the study investigated: (a) the difference between perceived occurrence of rape and occurrence consistent with the law; (b) awareness of the circumstances when consent can be legally given (e.g., if a person is drunk can they give consent?); (c) factors which may be associated with rape (for example, is it associated with age of first sexual intercourse?; does education on sexual abuse protect individuals from rape?; does choice of sexual partner [homosexual, heterosexual] vary the risk of rape?); (d) the alignment between fear of rape and its occurrence (for example, does fear of rape and other crimes correspond with the reported occurrence of reported crimes?); (e) participants' perceptions of who are rapists and actual experiences of who are victimisers (e.g., do the perceptions of who is a potential rapist correspond with the reality of who perpetrates rape?); (f) are childhood experiences of sexual abuse by parents associated with the child's experience of rape?; (g) does choice of sexual partner (homosexual, heterosexual) relate to risk of rape?; and, finally, (h) how these perceptions and experiences may differ between male and female student respondents. 


\section{Methodology}

An Internet-based questionnaire was devised to investigate consent prior to sexual intercourse. While this allowed for many people to be invited to participate in the study, it required the concepts to be clearly articulated, as participants were unable to seek clarification about any questions as they could with a face-to-face study. The need for consent in legal sexual relations is made clear in the Sexual Offences Act, 1991. The Act also provides a clear definition of sexual intercourse. While rape is clearly a subsect of acts which constitute sexual abuse, sexual abuse is more difficult to define for an Internet-based study. Consequently, while sexual intercourse was defined, no definition of sexual abuse was specified in the survey, and respondents were allowed to answer questions related to sexual abuse within their own frame of reference; however, the implication was that sexual abuse would refer to acts which excluded penetration. Students in a social science research class invited students at their university to participate and these participants were asked to further invite other students to participate. Via this snowball sampling, each student was asked to obtain 25 students to participate as part of their course work. The anticipated sample size was 525.

The survey included two standard scales, one for assessing the presence of IPV (Feldhaus et al., 1997) and the other for defining participants' experience, the Reason for Consenting to Unwanted Sex Scale (Humphreys \& Kennett, 2011). In addition, questions were asked about the sexual experiences of the participants. These questions included obtaining information to determine if the participant had been raped, either on the basis of age, lack of consent or fear. The study was approved by the Institutional Review Board of University of The Bahamas.

\section{Results}

Of the 879 persons who entered the survey, useful replies were obtained from 621 eligible respondents (i.e., 18 or over and registered as a University of The Bahamas student in the Fall of 2019), and these were retained for the analysis.

Consistent with the University of The Bahamas student population, $74.1 \%$ were females, and $25.4 \%$ were males, with $0.5 \%$ indicating that their sex was "other". Again, consistent with a university aged population, most respondents were aged between 18-20 years old (see Table 1). Overall, $72.7 \%$ of respondents had engaged in sexual intercourse. This figure was similar for both males and females $(72.4 \%$ of males and $72.7 \%$ for females, $\chi^{2}(1, N=614)=.004, p$ $=.95$.

Table 1

Distribution of Respondents' Ages

\begin{tabular}{lc}
\hline \multicolumn{1}{c}{ Age group } & $\%$ \\
\hline $18-20$ & 57 \\
$21-24$ & 29.1 \\
$25-30$ & 8.1 \\
Over 30 & 5.8 \\
\hline$N$ & 621 \\
\hline
\end{tabular}

Few participants (3.5\%) had not been exposed to any learning about sexual abuse (see Table 2). This suggests that when answering questions about sexual abuse, most respondents believed themselves to be aware of what constitutes sexual abuse. School was the most commonly reported place where participants had learnt about sexual abuse. However, the fact that a third of them did not report learning about sexual abuse at school suggests that some schools may not be teaching the subject matter or, at least, teaching it so that it is remembered. This lack of recall has been previously reported by Fielding et al. (2016a) in the case of illegal drug awareness. 
Table 2

Sources Identified by 621 Respondents of their Knowledge About Sexual Abuse

\begin{tabular}{lc}
\hline Source of learning about sexual abuse & $\%$ \\
\hline At school & 66.8 \\
At home & 50.7 \\
By my peers & 34.8 \\
At college/university & 28.5 \\
Not really, just what I picked up from the & 24.2 \\
Internet etc. & 23.5 \\
In a church setting & 3.5 \\
Not taught & \\
\hline
\end{tabular}

Note: Multiple answers allowed.

There was no strong evidence to support the idea that teaching about sexual abuse decreased the likelihood of females being raped $(p=.094)$. However, teaching at school was associated with a decrease in the percentage of women who reported being victims of sexual abuse $(31.7 \% \mathrm{v} 45.2 \%: p=$ .031), as was teaching in a church setting
$(17.5 \%$ v 31.7\%: $p=.015)$. This suggests that, in general, education on sexual abuse may be an influence which protects respondents from abuse.

While both men and women agreed that "strangers" were the most likely perpetrators of rape (see Table 3), male and female respondents tended to disagree on which other persons might be rapists. Usual partners, married or unmarried, were deemed to be least likely to commit rape; however, females thought that partners, usual or occasional, were equally likely to commit rape. This suggests a greater distrust of even usual partners amongst females than males, and by implication an awareness of date rape or acquaintance rape. This finding demonstrates some of the differences in perceptions towards rape associated with sex of participant - differences which reoccur throughout the results.

Table 3

Percentage of Participants, by Sex, Who Agreed that Selected Person Could Be a Rapist.

\begin{tabular}{|c|c|c|c|}
\hline \multirow[b]{2}{*}{ Persons who can rape their partner } & \multicolumn{2}{|c|}{ Sex of respondent } & \multirow{2}{*}{$\frac{X^{2}}{p}$} \\
\hline & $\begin{array}{c}\text { Male } \\
(N=149) \S\end{array}$ & $\begin{array}{c}\text { Female } \\
(N=422) \S\end{array}$ & \\
\hline A stranger & $98 \%$ & $98.1 \%$ & .314 \\
\hline A family member & $95.3 \%$ & $98.6 \%$ & .048 \\
\hline A friend & $90.6 \%$ & $97.9 \%$ & $<.001$ \\
\hline A partner with whom you occasionally have sexual intercourse & $85.9 \%$ & $93.9 \%$ & $<.001$ \\
\hline A husband/wife & $81.9 \%$ & $89.3 \%$ & .058 \\
\hline A partner with whom you usually have sexual intercourse & $81.1 \%$ & $93.4 \%$ & $<.001$ \\
\hline
\end{tabular}

Note: Multiple answers allowed. §Ns for males and females may vary by one or two due to non-response

Lack of consent and the fear of harm were recognised as being constituents of rape, by both males and females (see Table 4). Around $30 \%$ of participants agreed that rape could not occur inside marriage and around $10 \%$ thought that a victim needed to attempt to fight off their attacker if the sexual assault was to be considered rape. 
Table 4

Percentage of Respondents, by Sex, Agreeing to Selected Circumstances When Rape Occurs.

\begin{tabular}{|c|c|c|c|}
\hline \multirow[b]{2}{*}{ Circumstances under which rape occurs } & \multicolumn{2}{|c|}{ Sex of respondent } & \multirow{2}{*}{$\frac{X^{2}}{p}$} \\
\hline & $\begin{array}{c}\text { Male } \\
(N=149) \S\end{array}$ & $\begin{array}{c}\text { Female } \\
(N=422) \S\end{array}$ & \\
\hline $\begin{array}{l}\text { Rape occurs when one of those engaged in the sexual intercourse did not } \\
\text { consent }\end{array}$ & $94 \%$ & $97.2 \%$ & 0.23 \\
\hline $\begin{array}{l}\text { Rape occurs when one of those engaged in sexual intercourse consents due } \\
\text { to threats or fear of bodily harm from the other person }\end{array}$ & $89.3 \%$ & $88.6 \%$ & 0.83 \\
\hline A married couple cannot rape each other & $28.2 \%$ & $30.7 \%$ & 0.67 \\
\hline Rape only occurs when the victim tries to fight off their attacker & $10.7 \%$ & $7.6 \%$ & 0.41 \\
\hline Only females can be raped & $3.4 \%$ & $0.5 \%$ & 0.04 \\
\hline
\end{tabular}

Ns for males and females vary slightly due to non-response

Respondents were asked to rank their fear of eight selected crimes, arising from the classifications in official police statistics. It is apparent that the fear of crime does not reflect the reported incidence of the crimes (see
Table 5). While participants were most fearful of crimes against the person, females were more fearful of rape/sexual abuse than males, and males were more fearful than females of being held up and robbed.

\section{Table 5}

Mean Rank of Fear of Various Crimes, By Sex of Respondent, 1 Most Fearful, 8 Least Fearful, of These Crimes, And Ranked Occurrence of Crimes in 2018 - 1 Most Often Reported Crime, 8 The Least Often Reported.

\begin{tabular}{|c|c|c|c|c|c|}
\hline Crime & Sex & Mean Rank & SEM & $p$ & $\begin{array}{c}\text { Rank based on } \\
2018 \text { police } \\
\text { statistics* }\end{array}$ \\
\hline \multirow[t]{2}{*}{ Being raped } & Male & 4.35 & 0.195 & \multirow{2}{*}{$<.001$} & \multirow{2}{*}{8} \\
\hline & Female & 2.75 & 0.108 & & \\
\hline \multirow[t]{2}{*}{ Being shot } & Male & 3.45 & 0.218 & \multirow{2}{*}{.76} & \multirow{2}{*}{6} \\
\hline & Female & 3.52 & 0.119 & & \\
\hline \multirow[t]{2}{*}{ Being sexually abused } & Male & 5.22 & 0.195 & \multirow{2}{*}{$<.001$} & \multirow{2}{*}{7} \\
\hline & Female & 3.98 & 0.110 & & \\
\hline \multirow[t]{2}{*}{ Being held up and robbed } & Male & 3.83 & 0.140 & \multirow{2}{*}{.007} & \multirow{2}{*}{3} \\
\hline & Female & 4.24 & 0.076 & & \\
\hline \multirow[t]{2}{*}{ Being physically attacked by another } & Male & 4.24 & 0.152 & \multirow{2}{*}{.99} & \multirow{2}{*}{5} \\
\hline & Female & 4.24 & 0.083 & & \\
\hline \multirow[t]{2}{*}{ Having your home broken into } & Male & 3.84 & 0.177 & \multirow{2}{*}{$<.001$} & \multirow{2}{*}{2} \\
\hline & Female & 4.74 & 0.094 & & \\
\hline \multirow[t]{2}{*}{ Having your car stolen } & Male & 4.75 & 0.172 & \multirow{2}{*}{$<.001$} & \multirow{2}{*}{4} \\
\hline & Female & 5.77 & 0.100 & & \\
\hline \multirow[t]{2}{*}{ Having something stolen from your car } & Male & 6.21 & 0.157 & \multirow{2}{*}{0.25} & \multirow{2}{*}{1} \\
\hline & Female & 6.43 & 0.101 & & \\
\hline
\end{tabular}

Note: *Derived from data in: Royal Bahamas Police Force (2019). $p$ values from t-tests 
The differences in the rank order of fear of being a victim of rape between males and females was reflected in the different perceptions, $\chi^{2}(3, N=571)=25.207, p<$ .001 , that they had about how common it was for females to be sexually abused but not for how common it was for men to be sexually abused $\chi^{2}(3, N=573)=2.833, p=.42$, Table 6.

Most participants had experienced sexual intercourse, and only $2.8 \%$ had not experienced sexual intercourse after the age of 30 (see Figure 1). This indicates that not only had most engaged in sexual intercourse, but they also had personal experience of sexual intercourse with which to inform their responses.
Table 6

Participants' Attitude to Occurrence of Rape of Males and Females by Sex of Respondent

\begin{tabular}{|c|c|c|}
\hline \multirow{2}{*}{$\begin{array}{l}\text { Attitude of occurrence of } \\
\text { rape } \\
\text { Very common or } \\
\text { common for: }\end{array}$} & \multicolumn{2}{|c|}{ My sex is: } \\
\hline & Male & Female \\
\hline $\begin{array}{l}\text { Women in The Bahamas } \\
\text { to have sexual } \\
\text { intercourse against their } \\
\text { will? }\end{array}$ & $73.2 \%$ & $88.6 \%$ \\
\hline $\begin{array}{l}\text { Men in The Bahamas to } \\
\text { have sexual intercourse } \\
\text { against their will? }\end{array}$ & $29.5 \%$ & $35.1 \%$ \\
\hline
\end{tabular}

\section{Figure 1}

Cumulative Percentage of Respondents Experiencing Sexual Intercourse by Age Group of Respondents.

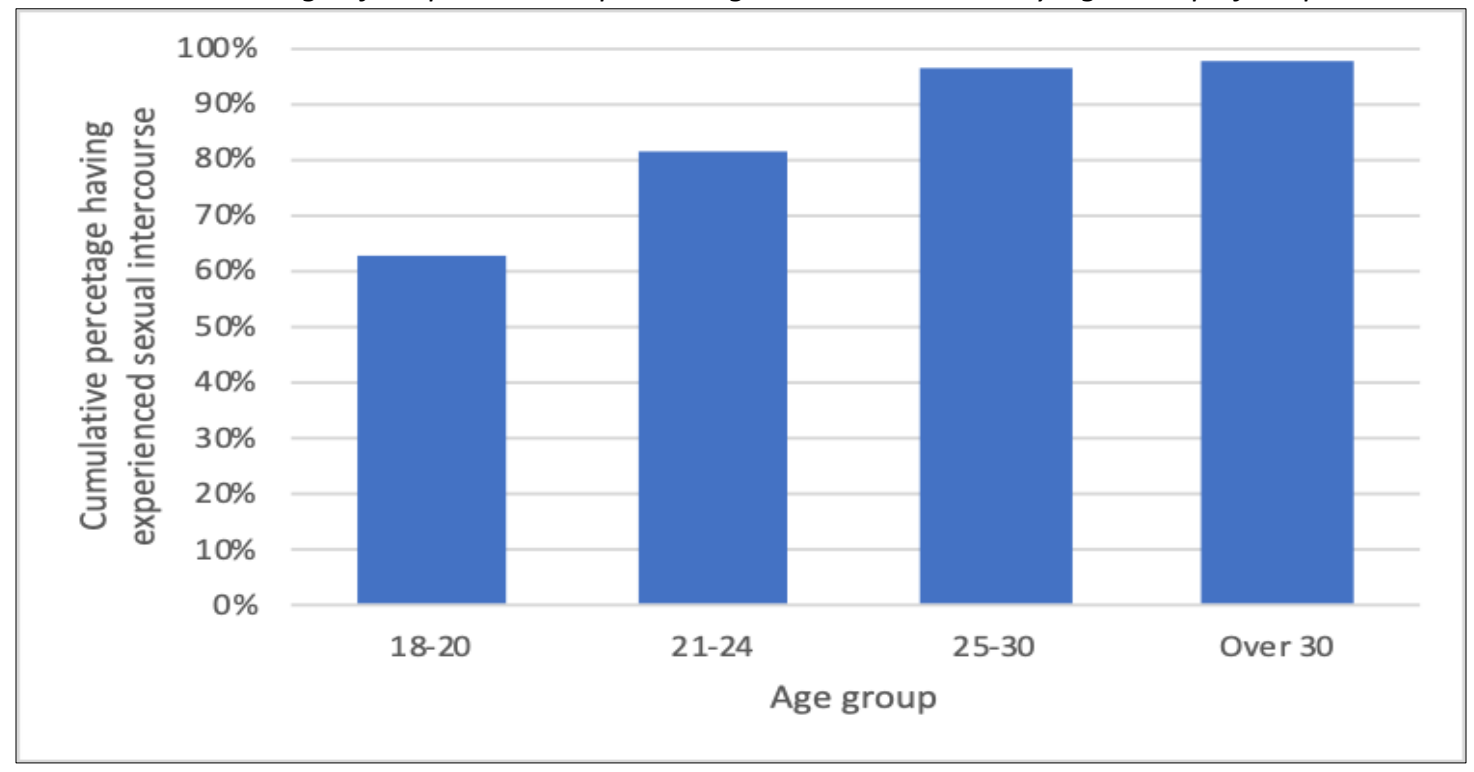

In each age group, a lower percentage of males than females were in a long-term relationship, that is married or in a relationship for one year or longer (Figure 2). The percentages of males and females in long-term relationships increase with age, likewise the gap between males and females, although it should be remembered that we only have data from students, and so generally young respondents. 


\section{Figure 2}

Percentage of Participants in a "Long-Term Relationship" by Sex and Age Group.

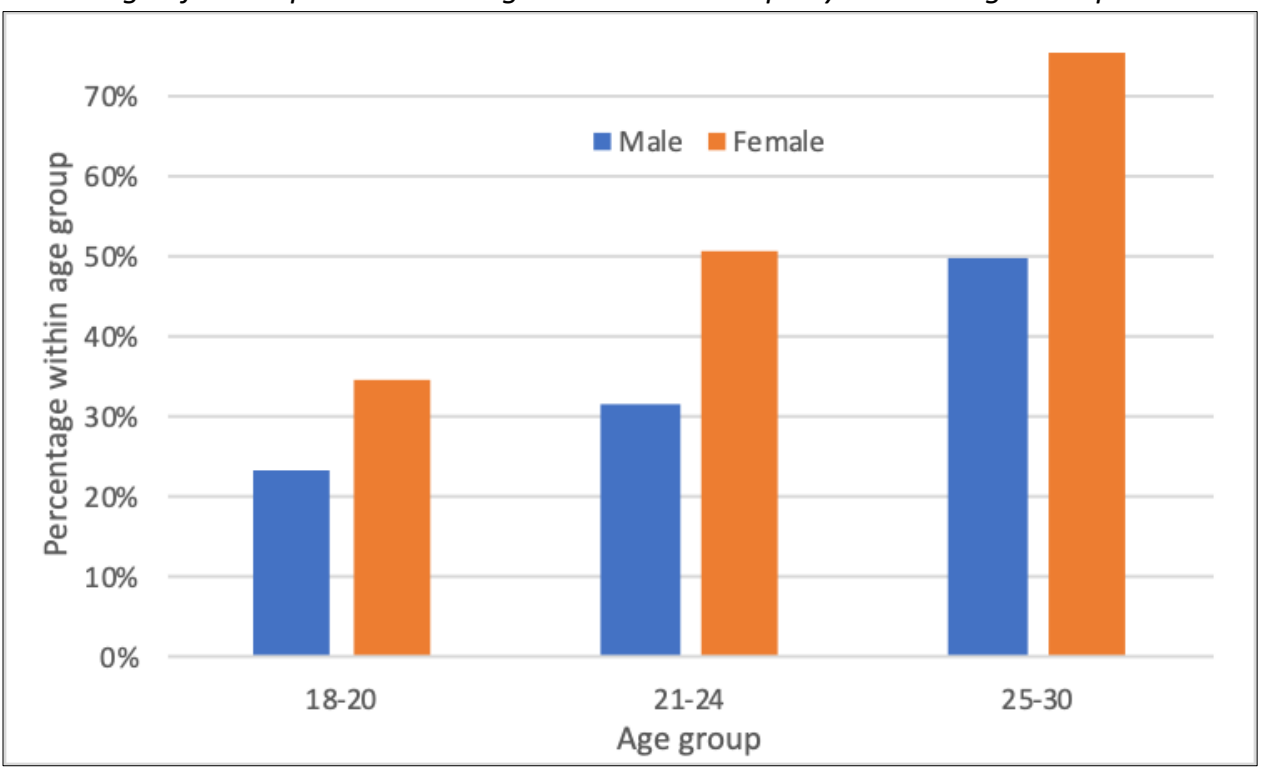

Overall, while there was no statistical difference between the ages at which males and females first had sexual intercourse $\left(\chi^{2}\right.$ $(7, N=425)=13.171, p=.068)$, the earlier engagement of males in this activity is expected and also seen here, so a one-sided test, would be statistically significant, $p=$ .034 , see Table 7). It is also apparent that by the time participants joined the university at about age 18, most had already experienced sexual intercourse; consequently, school-age sexual intercourse is not uncommon.

Table 7

Age of First Sexual Intercourse by Sex of Respondent

\begin{tabular}{|c|c|c|c|c|}
\hline \multirow{2}{*}{ Age } & \multirow{2}{*}{ Male } & \multirow{2}{*}{ Female } & \multicolumn{2}{|c|}{ Cumulative percentage } \\
\hline & & & Male & Female \\
\hline Under 14 & $8.7 \%$ & $3.1 \%$ & $8.7 \%$ & $3.1 \%$ \\
\hline 14 & $5.4 \%$ & $3.3 \%$ & $14.1 \%$ & $6.4 \%$ \\
\hline 15 & $4 \%$ & $7.8 \%$ & $18.1 \%$ & $14.2 \%$ \\
\hline 16 & $17.4 \%$ & $14.6 \%$ & $35.5 \%$ & $28.8 \%$ \\
\hline 17 & $12.1 \%$ & $11.3 \%$ & $47.6 \%$ & $40.1 \%$ \\
\hline 18 & $16.8 \%$ & $19.5 \%$ & $64.4 \%$ & $59.6 \%$ \\
\hline $19-24$ & $11.4 \%$ & $13.4 \%$ & $75.8 \%$ & $73 \%$ \\
\hline Over 24 & 0 & $0.5 \%$ & $75.8 \%$ & $73.5 \%$ \\
\hline $\begin{array}{l}\text { I have never had sexual } \\
\text { intercourse }\end{array}$ & $24.2 \%$ & $26.6 \%$ & $100 \%$ & $100.1 \%$ \\
\hline$N$ & 149 & 425 & & \\
\hline
\end{tabular}

Note: Percentages do not sum to $100 \%$ due to rounding. 
The circumstances under which participants had sexual intercourse indicate that some had not only been victims of abuse, but some had also abused others by having sex with underage persons or when their partners were unable to give consent. The first experience of sexual intercourse was more likely for males $(59.6 \%)$ than females $(49.0 \%), \chi^{2}(2, N$ $=409)=6.045, p=.049$, to have had a positive influence on their current expectations of sexual intercourse. This may indicate that overall, females were more likely than males to have engaged in their first sexual intercourse experience against their will, or the experience caused them some other distress. Except in the earliest age group, females were more likely to be forced into their initial sexual encounter than males. For those whose first sexual encounter occurred when they were over 24, all respondents indicated that it occurred with their consent (see Figure 3).

\section{Figure 3}

Percentage, by Sex, of Males and Females Having First Sexual Intercourse Against Respondent's Will by Age at First Sexual Intercourse

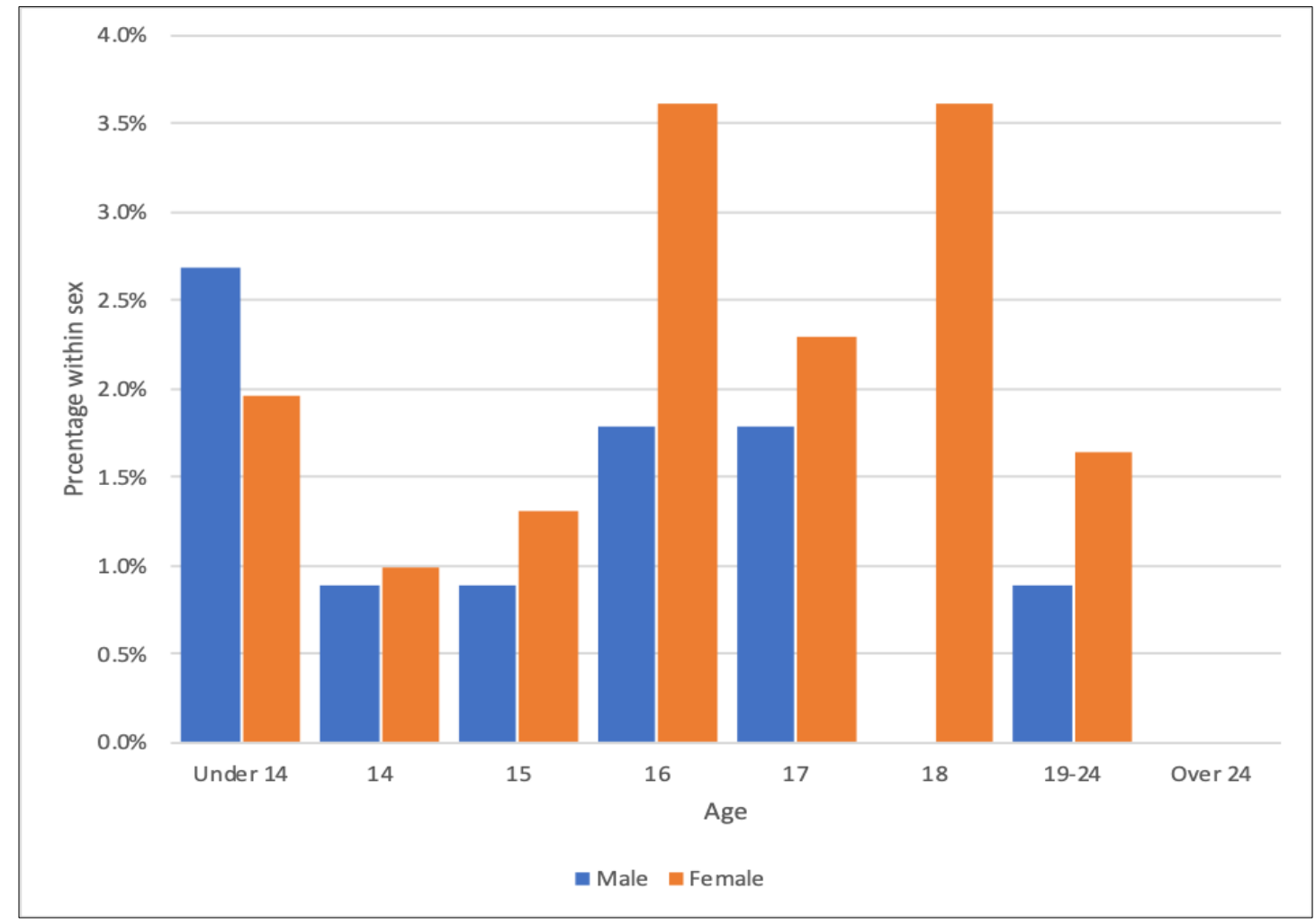

The circumstances under which participants engaged in sexual intercourse allow for the opportunity for one or both participants to be abused or raped. Clear consent is not always given, and the use of alcohol or drugs further prevents consent being given. Females were more likely than males to engage in sexual intercourse through fear, and more males than females admitted to (probably) statutory rape through having sexual intercourse with a person under the age of 16 (see Table 8). Some participants, appeared to either not know, or not care, that the circumstances under which they engaged in sexual intercourse were those when consent was not given, either due to fear or some incapacitation. 
Table 8

Percentage of Male and Female Respondents Who Engaged in Sexual Intercourse Under Selected Circumstances

\begin{tabular}{lccc}
\hline & \multicolumn{1}{c}{ Sex of respondent } & $X^{2}$ \\
\hline $\begin{array}{l}\text { Circumstances under which respondents had engaged in sexual } \\
\text { intercourse }\end{array}$ & $\begin{array}{c}\text { Male } \\
(N=112) \S\end{array}$ & $\begin{array}{c}\text { Female } \\
(N=304) \S\end{array}$ & $p$ \\
\hline $\begin{array}{l}\text { Always give clear consent } \\
\text { Have you ever had sexual intercourse when you were physically or }\end{array}$ & $69.7 \%$ & $79.3 \%$ & .123 \\
$\begin{array}{l}\text { mentally unable to give consent? (e.g.: drunk or high) } \\
\text { Have you ever had sexual intercourse when your partner was physically } \\
\text { or mentally unable to give consent? (e.g.: drunk or high) }\end{array}$ & $18.3 \%$ & $24.0 \%$ & .236 \\
$\begin{array}{l}\text { Have you ever had sexual intercourse with an individual because you } \\
\text { were afraid of them? }\end{array}$ & $2.8 \%$ & $15.4 \%$ & .888 \\
$\begin{array}{l}\text { Have you ever had sexual intercourse with a person under the age of } \\
16 ?\end{array}$ & $11.9 \%$ & $4.0 \%$ & .002 \\
\hline
\end{tabular}

$N$ values vary slightly between circumstances due to non-response.

A total of $35.5 \%$ of females had been raped due to their age $(18.9 \%)$ at first sexual intercourse (15 or less) and due to being unable to give consent $(16.6 \%)$ when over 15. This compares with $35.8 \%$ of males having been raped due to their age at first sexual intercourse (15 or less, $23.9 \%$ ) and due to being unable to give consent when over 15 (11.9\%). The self-reported responses of ever being raped, show a cumulative pattern of a steady increase in lifetime rape for females and a much lower cumulative increase in the case of males. By age 19-24, 23.1\% of females had experienced rape, (see Figure 4).

\section{Figure 4}

Cumulative Percentage of Respondents Self-Reporting Rape by Age at First Sexual Intercourse. Percentages of Those Who Ever Engaged in Sexual Intercourse.

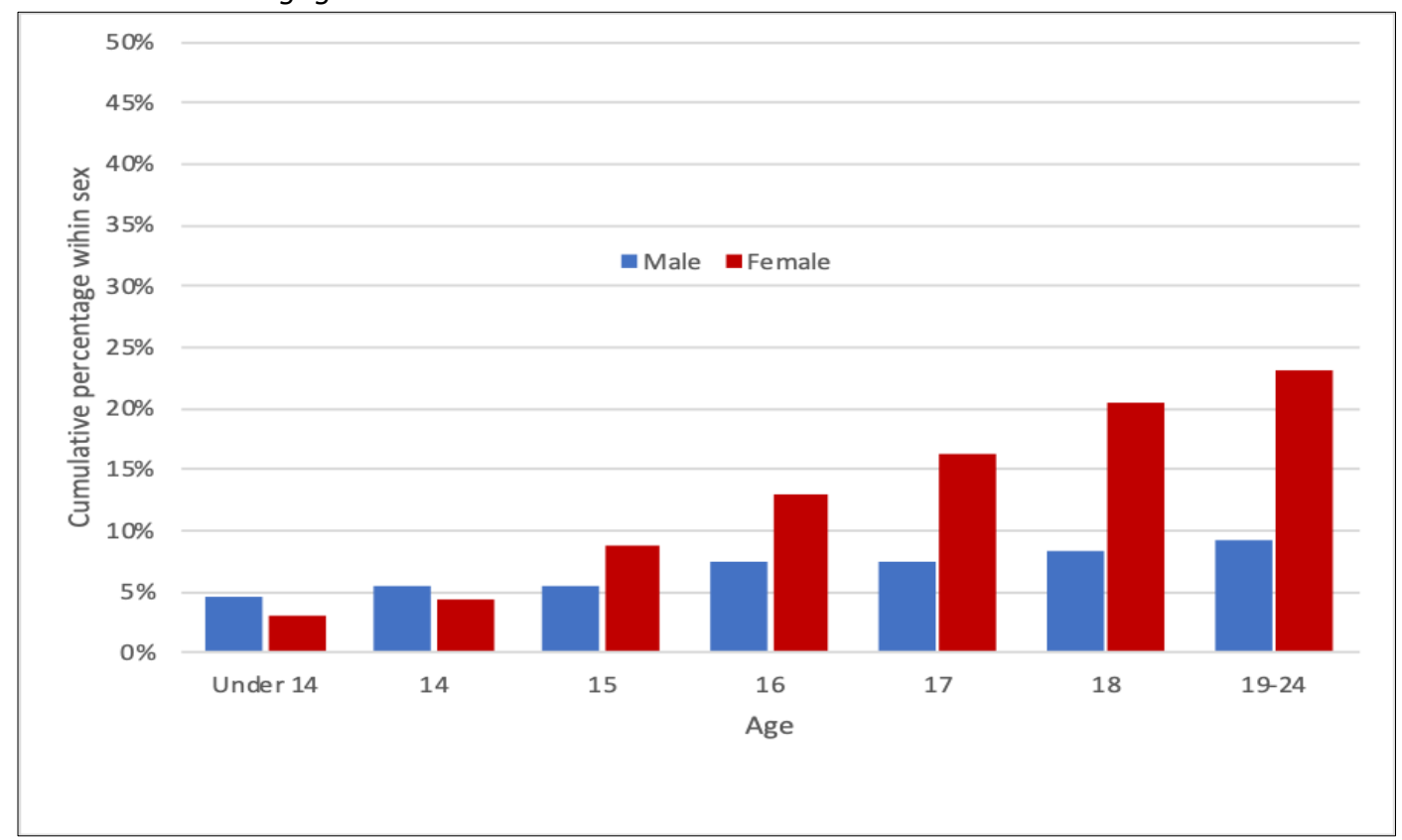


Based upon the respondents' answers to questions focused on age of engaging in sexual intercourse, consent and ability to consent etc. (Table 9), we can redraw the graph based upon our estimated events of rape. In this latter case, the cumulative percentage gap of males and females who were victims of rape closes; however, males were more likely than females to be raped at a young age. The estimated occurrence of rape indicates not only a higher incidence of rape, but a higher incidence of male rape, which outpaces that in the female population until the 19-24 age group (see Figure 5).

\section{Figure 5}

Estimated Cumulative Percentage of Students Raped (Due to Lack of Consent or Age or Fear) by Age of First Sexual Intercourse. Percentages of Those Who Ever Engaged in Sexual Intercourse.

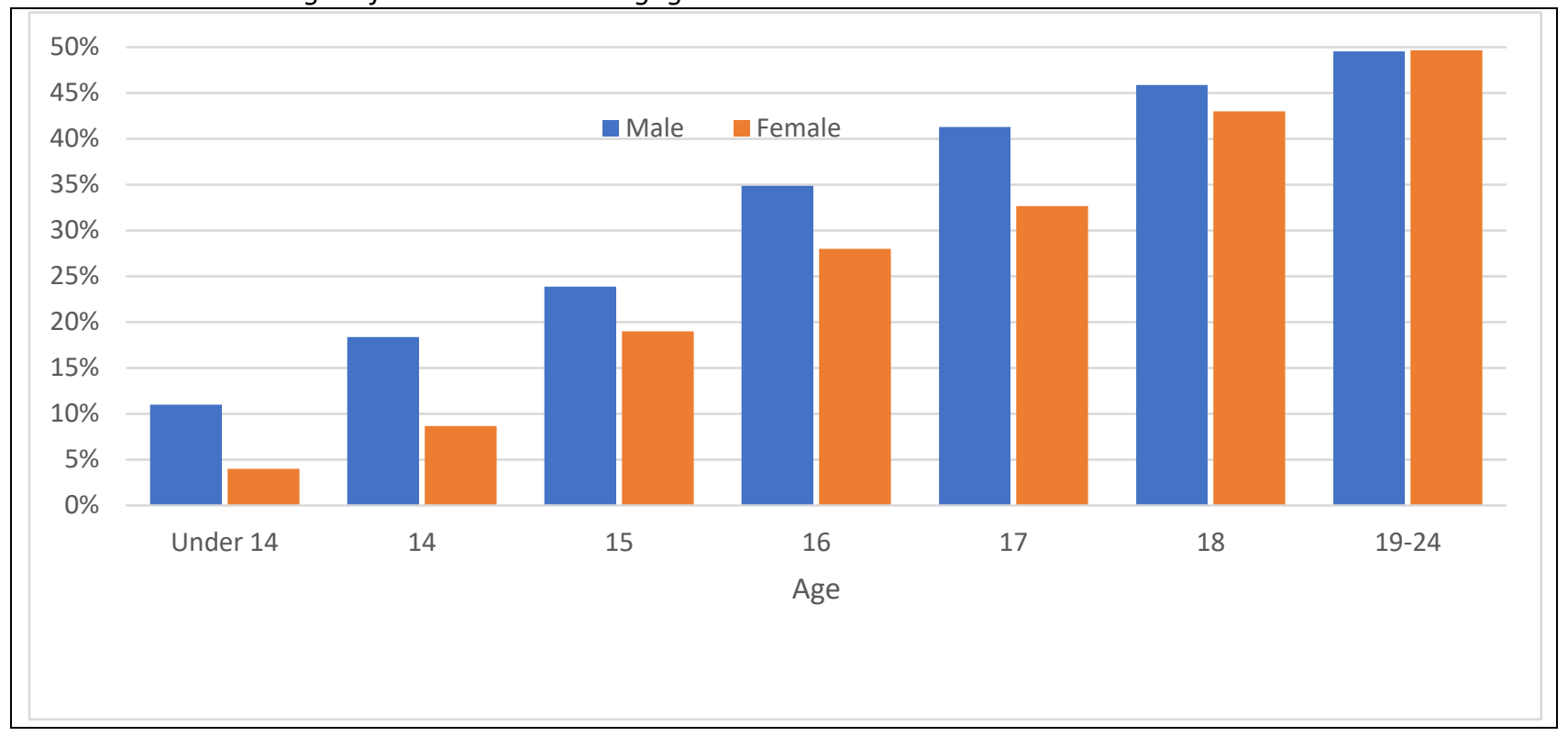

Table 9

Circumstances Under Which Respondents Engaged in Sexual Intercourse Which are Associated with Rape/Sexual Abuse, by Sex of Respondent.

\begin{tabular}{|c|c|c|c|}
\hline & Sex of respondent & $x^{2}$ & \\
\hline Action resulting in potential/actual rape & Male $(N=109)$ & Female $(N=30)$ & $p$ \\
\hline Raped through not being able to give consent & $18.3 \%$ & $24.0 \%$ & .236 \\
\hline Raped by age at first sex & $18.1 \%$ & $14.1 \%$ & .236 \\
\hline Not always giving clear consent to sex & $21.1 \%$ & $14.0 \%$ & .123 \\
\hline $\begin{array}{l}\text { Ever had sexual intercourse with an individual because they } \\
\text { were afraid of them }\end{array}$ & $2.8 \%$ & $11.0 \%$ & .002 \\
\hline
\end{tabular}

Sexual intercourse was typically engaged in by respondents with those of the opposite sex, and while few females had sexual intercourse with other females, they were more likely to have experienced sexual intercourse with both sexes than males (see Table 10). 
Table 10

Choice of Sexual Partners by Sex of Respondents Who Have Engaged in Sexual Intercourse.

\begin{tabular}{|c|c|c|}
\hline \multirow[b]{2}{*}{ Sex of partner(s) } & \multicolumn{2}{|c|}{ Sex of respondent } \\
\hline & $\begin{array}{c}\text { Male } \\
(N=109)\end{array}$ & $\begin{array}{c}\text { Female } \\
(N=298)\end{array}$ \\
\hline Only male & $9.2 \%$ & $85.2 \%$ \\
\hline Only female & $88.1 \%$ & $1 \%$ \\
\hline Both male and female & $2.8 \%$ & $13.8 \%$ \\
\hline
\end{tabular}

Females were more likely than males to be victim of IPV, irrespective of the sex of their intimate partner(s), as seen in Table 11. It should be noted that relatively few respondents were apparently bisexual, except for females, or homosexual, so these percentages should be treated with caution.

Table 11

Percentage of Respondents Being Victims of IPV by Sex and Sexual Orientation

\begin{tabular}{lcc}
\hline $\begin{array}{l}\text { Sexual orientation } \\
\text { based upon choice } \\
\text { of sexual partner(s) }\end{array}$ & \multicolumn{2}{c}{ Participant suffers from IPV } \\
\hline Heterosexual & $9.4 \%(N=96)$ & $26.9 \%(N=253)$ \\
Bisexual & $0.0 \%(N=3)$ & $39.0 \%(N=41)$ \\
Homosexual & $20.0 \%(N=10)$ & $100.0 \%(N=3)$ \\
\hline
\end{tabular}

In the case of females, there was a strong intergenerational effect of IPV. Respondents whose mothers had suffered from IPV were more likely to in turn be victims of IPV than those respondents whose mothers had not been victims of IPV, $\chi^{2}(1, N=298)=9.567$, $p=.002$, (see Table 12).

Table 12

Intergenerational Association of IPV in Female Respondents

\section{Female participant} suffers from IPV

Mother suffered

\begin{tabular}{lrr} 
from IPV & Yes & No \\
\hline Yes & $47.7 \%$ & $29.0 \%$ \\
No & $52.3 \%$ & $71 \%$ \\
\hline
\end{tabular}

Further, it can be seen that in the case of females, there was an association between age of first sexual intercourse and being a victim of IPV (see Figure 6). This suggests that, particularly when the first sexual experience was to some extent coerced, IPV might start in early teenage years. Overall, $12.7 \%$ of males and $26.4 \%$ of females consented to unwanted sexual intercourse.

\section{Figure 6}

Percentage of Females Suffering from IPV by Age at First Sexual Intercourse.

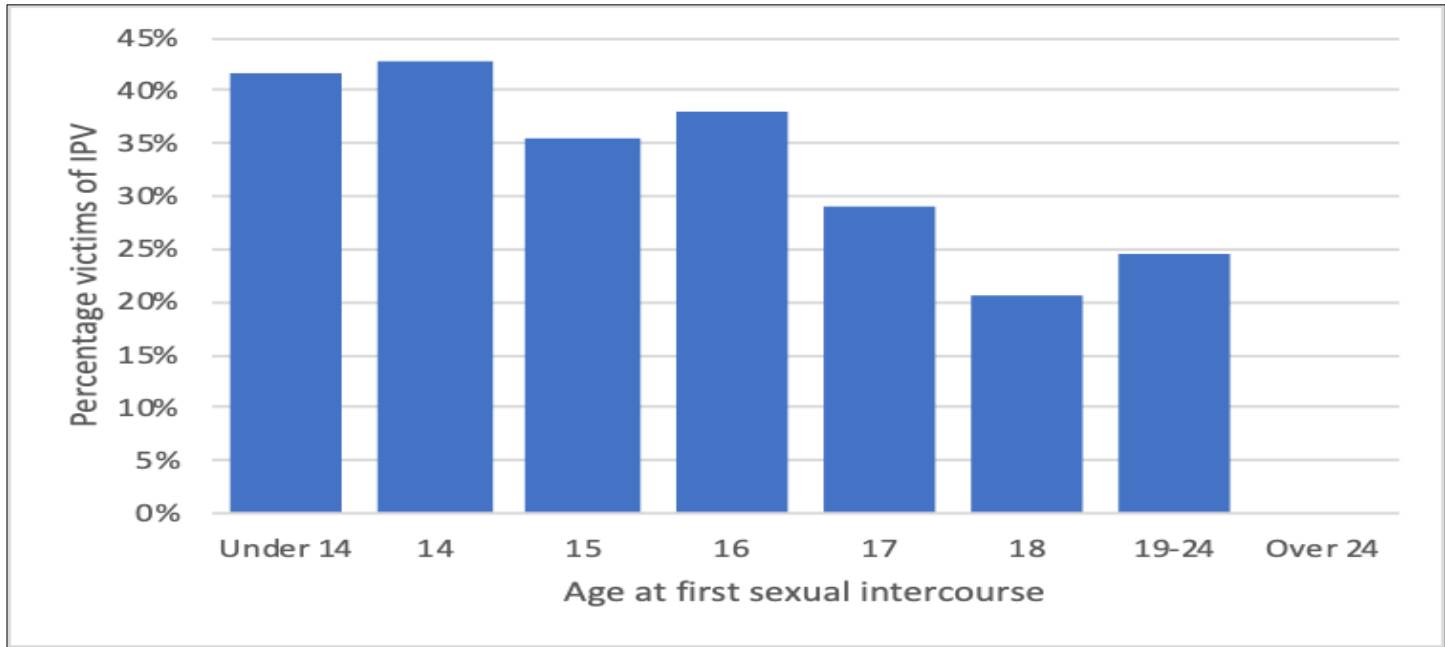


Females who engaged in sexual intercourse at earlier ages where more likely to be victims of IPV that those who experienced sexual intercourse at a later age. While self-reported rape may appear a cause for concern (Table 13), rape can only occur in the group of people who have experienced sexual intercourse. When the percentage of students who admitted to being raped is assessed within the total population of respondents, the differences between male and female rape becomes even more apparent, as well as the fact that females are more likely to be subject to multiple rape events than males (see Table 14).

Table 13

Ever Raped (Self-Reported) by Age and Sex of Respondents

\begin{tabular}{lcccc}
\hline \multirow{2}{*}{$\begin{array}{l}\text { Sex of } \\
\text { respondent }\end{array}$} & $18-20$ & $21-24$ & $25-30$ & Over 30 \\
\hline Male & $3.6 \%$ & $16.3 \%$ & - & - \\
Female & $20.3 \%$ & $24.7 \%$ & $25.7 \%$ & $29.6 \%$ \\
\hline
\end{tabular}

Table 14

Frequency of Reported Rape by Sex of Respondent

Sex of respondent

\begin{tabular}{lrr} 
Raped & Male & \multicolumn{1}{c}{ Female } \\
\hline No, never & $90.7 \%$ & $76.9 \%$ \\
Only once & $5.6 \%$ & $13.6 \%$ \\
Sometimes & $3.7 \%$ & $6.5 \%$ \\
Often & $0 \%$ & $1.7 \%$ \\
Frequently & $0 \%$ & $1.4 \%$ \\
\hline $\mathrm{N}$ & 108 & 294 \\
\hline
\end{tabular}

None of the males reported their rape, and $17.3 \%$ of females reported their rape. This highlights the underreporting which is associated with an extreme form of sexual abuse. Of those who reported their sexual abuse (Table 15), which may or may not have included rape, only about two thirds of females had never suffered sexual abuse.
Additionally, repeat events were more common for females than males, which again reinforces the perceptions expressed in Table 6 that sexual abuse of women is common or very common.

\section{Table 15}

Occurrence of Self-Reported Sexual Abuse By Sex of Respondents.

\begin{tabular}{lcc}
\hline I have been & \multicolumn{2}{c}{ Sex of respondent } \\
sexually abused & Male & Female \\
\hline No, never & $89.9 \%$ & $64.6 \%$ \\
Only once & $4.6 \%$ & $20.1 \%$ \\
Sometimes & $5.5 \%$ & $10.5 \%$ \\
Often & $0 \%$ & $3.1 \%$ \\
Frequently & $0 \%$ & $1.7 \%$ \\
\hline$N$ & 109 & 294 \\
\hline
\end{tabular}

Unlike rape, the reporting of sexual abuse was equally common by both male and female victims, with $23 \%$ of males and females reporting the abuse. However, this figure again indicates the lack of reporting to civil authorities, and so reduces their ability to curtail the activities of victimisers.

IPV was related to being assessed as a victim of rape at some time in the life of the respondent for females $\chi^{2}(1, N=299)=$ $17.589, p<.001$, but not for males $\chi^{2}(1$, $N=109)=.123, p=.761$, as shown in Table 16. While this does not mean that rape is necessarily a component of IPV, those who were ever victims of rape can be expected to have a higher risk of being victims of IPV.

Table 16

Relationship Between Assessed Rape and Being a Victim of IPV of 211 Female and 109 Male Respondents.

Assessed to be ever a victim of rape

\begin{tabular}{|c|c|c|}
\hline Sex & IPV & No IPV \\
\hline Male & $54.5 \%$ & $49.0 \%$ \\
\hline Female & $71.6 \%$ & $45.0 \%$ \\
\hline
\end{tabular}


The assessment of rape from the survey, including having sex when fearful of their partner, suggests higher experiences of rape than was self-reported. This again has implications for the figures of reported rape because if people do not know that they have been victims of rape, it would never occur to them to report the event. Table 17 suggests that the majority $(51.7 \%)$ of female participants had been assessed as being victims of rape at some time in their lives compared to a similar percentage of males $(49.1 \%)$.

Table 17

Relationship Between Self-Reported Rape and Assessed as Raped, by Sex of Respondents.

\begin{tabular}{clrr} 
& & \multicolumn{2}{c}{ Self-reported } \\
$\begin{array}{c}\text { Sex of } \\
\text { respondent }\end{array}$ & Assessed & Not raped & Raped \\
\hline $\begin{array}{c}\text { Male } \\
(N=108)\end{array}$ & Not raped & $50.9 \%$ & $0 \%$ \\
& Raped & $39.8 \%$ & $9.3 \%$ \\
$\begin{array}{c}\text { Female } \\
(N=294)\end{array}$ & Not raped & $45.2 \%$ & $3.1 \%$ \\
& Raped & $31.6 \%$ & $20.1 \%$ \\
\hline
\end{tabular}

On reflection, $12.7 \%$ of males and $26.4 \%$ of females agreed that they had consented to sexual intercourse against their will. The lack of appreciation that consent is important in an act which becomes rape without consent is illustrated in Table 18 where $9.2 \%$ of all respondents had consented to an act which they did not want, and so may also have been raped, even though they did not acknowledge it.

\section{Table 18}

Relationship Between Consenting to Sexual Intercourse Against the Respond's Will and Ever

Being Raped, $N=401$.

\begin{tabular}{|c|c|c|}
\hline \multirow{2}{*}{$\begin{array}{l}\text { Self-reported: } \\
\text { Ever raped }\end{array}$} & \multicolumn{2}{|c|}{$\begin{array}{c}\text { On reflection respondent had } \\
\text { consented to sexual intercourse } \\
\text { against their will }\end{array}$} \\
\hline & Yes & No \\
\hline Not raped & $9.2 \%$ & $70.3 \%$ \\
\hline Raped & $12.7 \%$ & $6.7 \%$ \\
\hline
\end{tabular}

In the case of females, the most common person with whom they had sexual intercourse against their will, even if they "consented," were those people with whom the female was having a relationship (see Table 19). This list of persons is at variance with that given in Table 3. As such, it highlights the difference of perceived and actual abusers.

Table 19

Classifications of Persons Who Had Unwanted Sex with Female Respondents

\begin{tabular}{l} 
Females who reported having sex \\
against their will with \\
\hline $\begin{array}{l}\text { People in a "relationship" with the } \\
\text { victim }\end{array}$ \\
Others, known to the victim \\
Family members \\
Known to the victim and in a \\
possible position of power* \\
Others, unknown to the victim \\
Note: ${ }^{*}$ Includes babysitter, church member, co- \\
worker, landlord \\
Of those people in a relationship with the \\
victim, 93.8\% of them were either \\
boyfriends, ex-boyfriends or partners. Only \\
one person stated that their husband had had \\
sex with them against their will, and this \\
probably reflects the fact that few persons in \\
a student population are married. While
\end{tabular}


consenting to sex against their will does not automatically imply that the woman was raped, it does suggest that pressure/encouragement of some sort was exerted upon her, which might extend to rape.

In the case of female respondents, experiences of sexual abuse and rape were associated with their feelings of safety. The spill-over effects of fear of rape/sexual abuse can be appreciated in Table 20 where even those females who did not feel that they had been sexually abused, reported sexual abuse as affecting their feeling of safety.

Table 20

Association Between Being a Victim Of Sexual Abuse And Feeling Of Safety, Female Respondents.

\begin{tabular}{lcc}
\hline & \multicolumn{2}{c}{$\begin{array}{c}\text { Ever sexually } \\
\text { abused }\end{array}$} \\
$\begin{array}{l}\text { Do you agree that being a victim } \\
\text { of sexual abuse/rape has made } \\
\text { you fearful of your safety? }\end{array}$ & No & Yes \\
\hline Strongly agree & $5.8 \%$ & $20.2 \%$ \\
Agree & $5.3 \%$ & $20.2 \%$ \\
Somewhat agree & $1.6 \%$ & $17.3 \%$ \\
Neither agree nor disagree & $1.6 \%$ & $17.3 \%$ \\
Somewhat disagree & $1.1 \%$ & $6.7 \%$ \\
Disagree & $1.1 \%$ & $8.7 \%$ \\
Strongly disagree & $0.5 \%$ & $5.8 \%$ \\
Never a victim of sexual & $83.1 \%$ & $3.8 \%$ \\
abuse/rape & 189 & 104 \\
\hline$N$ & &
\end{tabular}

A similar pattern on feelings of safety was found amongst those females who reported that they had been ever been raped, as seen in Table 21.
Table 21

Association Between Being a Victim of Admitted Rape and Feeling of Safety (females only).

Ever raped

Do you agree that being a victim of sexual abuse/rape has made Not you fearful of your safety? raped Raped

\begin{tabular}{lrc} 
Strongly agree & $7.6 \%$ & $22.1 \%$ \\
Agree & $5.8 \%$ & $26.5 \%$ \\
Somewhat agree & $4.0 \%$ & $17.6 \%$ \\
Neither agree nor disagree & $5.3 \%$ & $13.2 \%$ \\
Somewhat disagree & $1.3 \%$ & $8.8 \%$ \\
Disagree & $2.7 \%$ & $7.4 \%$ \\
Strongly disagree & $1.8 \%$ & $4.4 \%$ \\
Never a victim of sexual & & \\
abuse/rape & $71.6 \%$ & \\
\hline N & 225 & 68 \\
\hline Exact $X^{2}(7, N=293)=112.1, p<.001$. & & \\
\end{tabular}

Below we focus on female respondents and aspects of the "pressure" brought to them to consent to unwanted sexual intercourse. A total of 71 females completed the Consent to Unwanted Sexual Intercourse Scale. The overall pressure score of this group was 59.1 $(S E=4.57)$ and Cronbach's $\alpha$ was .95. Those who admitted to having ever been raped were associated with the higher mean pressure scores than those who did not acknowledge having been raped $(t(67.7)=4.175, p<.001$; see Table 22).

Table 22

Consent to Unwanted Sexual Intercourse Scale Means (females only).

\begin{tabular}{lcr}
\hline $\begin{array}{l}\text { Ever raped, self- } \\
\text { reported }\end{array}$ & Mean & $\begin{array}{r}\text { Std. Error } \\
\text { Mean }\end{array}$ \\
\hline Raped & 73.1 & 6.30 \\
Not raped & 39.7 & 4.94 \\
\hline
\end{tabular}

Similarly, those who were victims of IPV had a higher mean pressure score than those who were not $(t(69)=3.644, p<.001, p=.001$; see Table 23). This suggests that those who 
were also victims of IPV suffered similar pressure to consent to sex against their will than those who were not victims of rape. In part, this is due to the fact that $55.9 \%$ of those who admitted to being a victim of rape were also victims of IPV, compared to $20.9 \%$ of non-admitted rape victims who were victims of IPV.

Table 23

Consent to Unwanted Sexual Intercourse Scale Means (females only).

\begin{tabular}{lrr}
\hline Victim of IPV & Mean & SE Mean \\
\hline Yes & 73.4 & 5.94 \\
No & 42.6 & 5.96 \\
\hline
\end{tabular}

\section{Discussion}

When considering the results, we must not forget that the data refer to university students, not the general population of The Bahamas. This means that the results refer to younger persons in the population, around 18-24 years old, and they represent the more educated members of society. Notwithstanding this limitation, our study provides a useful start in uncovering some of the issues and complexities surrounding consent with respect to sexual intercourse. As such, it allows us to identify areas of concern with regard to rape, and the differences in actions and attitudes of males and females.

Some respondents had already experienced sexual encounters which appear to have been criminal events. This is consistent with the Bahamas Ministry of Health STEPS survey (2019) which found that in the wider adult population, some $11.4 \%$ had experienced sexual intercourse before the age of 15 . So the data support our hypothesis that there is a difference between perceived occurrence of rape and its occurrence consistent with the law. Some students also admitted to having been perpetrators of sexual abuse/rape by having sex with underage persons. This suggests that students are either ignorant of the law or feel that the sexual partner in their private life is beyond the protection/reach of the law. This is an attitude which was made evident in the marital rape debate and public comments made by Government ministers who indicated that sexual intercourse, particularly within marriage, was a private matter and, so, beyond the reach of legislation to protect either party ("Rolle: Marital Rape is a Private Issue," 2017). This is compounded by the religious teaching that because men and women become spiritually one upon marriage (Russell, 2020), it is impossible for one spouse to force the other into unwanted sexual activity. Alternatively, despite the students' exposure to sex education at school, it may have failed to have had an impact upon their actions, in a similar way school education concerning illegal drugs is not always successful (Fielding et al., 2016b).

Interpreting the data according to the law, many students failed to recognise that they had been sexually abused/raped. This points to inadequate education regarding sexual abuse and curtails the ability of the authorities to enforce the law regarding abuse or rape, as these events would not be reported. Education regarding sexual abuse should assist women in avoiding situations in which they might be raped, and so teaching men the requirements for consensual sexual relations, be they with a short--term or longterm partner. Further, this lack of appreciation concerning behaviours which infringe the law, contribute to the under reporting of sexual abuse/rape, and help to protect victimisers from the law.

The common use of alcohol by both males and females, and particularly marijuana by males, may contribute to either forced sexual encounters or sexual experiences where one or both participants are unable to give consent (Bahamas Ministry of Health, 2018). This use of drugs and alcohol is of concern as the country is considering legalising private consumption of cannabis, as it raises the 
question could this result is greater sexual abuse/rape due to risk taking (Metrik, et al, 2012) and the inability for consent to be given or obtained before engaging in sexual intercourse, particularly as cannabis raises sexual pleasure (Weller \& Halikas, 1984), and so may give rise to coercive sex.

The study confirmed misconceptions surrounding victimisers of rape/sexual abuse, which were also noted within college students in The Bahamas by Aranha (2016b). The perception of who was most likely to be a rapist was dissimilar to the actual experiences of respondents reported in this study. This suggests that education on sexual abuse may need to place greater emphasis on who may be victimisers, particularly on daterape or acquaintance rape. Some respondents were of the view that rape required some sort of violence. As such, this idea conforms with the law in some other jurisdictions as noted in the introduction, but not within The Bahamas. The association between sexual abuse and rape demonstrates the continuum between these. This raises the question as to whether abusers in The Bahamas become rapists. Further, given the fact that victims can become victimisers (Glasser et al., 2001), the occurrence of abuse is providing a larger than possibly expected pool of people from which victimisers may arise. This would suggest that more needs to be done to make people aware of the longer-term concerns associated with early abuse, as demonstrated in Figures 3 and 6.

Men indicated that they had less commitment to their sexual partners than females. This is consistent with the 2019 Bahamas Ministry of Health study which found that men had had more sexual partners than women. This lack of long-term association of males with their partners may suggest that men see females as fulfilling a sexual purpose, and one that may be unrelated to a long-term respectful relationship focused on establishing a family. This finding may explain why men exert pressure on women to consent against their will to engage in sex. This possible misalignment of views on sex of males and females can understandably result in coercion or even rape as males attempt to obtain sexual favours which women may be unwilling to provide.

The data situated rape in an environment of on-going violence in the life of victims. This study confirmed again the link between IPV and sexual abuse. This ratifies the link between physical violence and sexual abuse in homes in The Bahamas reported by Plumridge and Fielding (2009). The differences in the prevalence of IPV associated with choice of sexual partner (Table 11) should be interpreted with caution due to the small number of observations in some groups, but the results are consistent with others studies (which indicated higher levels of IPV in non-heterosexual groups (Rothman et al., 2011). The intergeneration effects of IPV in the female student population indicates that IPV is probably considered normal for a sizeable percentage of students. If this is so, this may also result in the abuse not being reported. Although male rape was rare, the stigma associated with it probably contributed in none of these victims reporting the event. This silence can only be detrimental to the long-term wellbeing of the victim. However, given the prevailing attitudes to what it means to be male in The Bahamas (Strachan, 2013) the silence of victims is understandable. However, it also means that victimisers can escape the attention of the law. The finding that males were at most risk of abuse at a young age, may suggest that these people are victims rather than persons willingly engaging in sexual intercourse. This suggests that reports of child abductions and in some cases sexual assault, which have initiated the drafting of the so-called Marco's Law (Virgil, 2013) to protect children are a necessary development, as some abductions 
may have resulted in sexual abuse (Cooper, 2019). Our data may represent homosexual or heterosexual activity with minors, with or without mutual consent, as alleged in the Bahamian press (Scavella, 2020). Alternatively, in the case of heterosexual sexual intercourse, Nicolls et al. (2014) noted that school age males typically engaged in sexual intercourse with females who were younger or of a similar age, so either or both parties might have been underage.

The apparent vulnerability of boys to being sexually abused is a concern. Although the study included only a small number of males who had admitted to being abused at an early age, this again may suggest the unwillingness of society to expose such abuse. The report of a self-confessed rapist in the media who claimed he was abused as a child should not be ignored ("Man Accused of Rape", 2011) as he is an example of a child victim who may have received little help when a victim, and then in adulthood he became a victimiser. This is another example where society fails to pay the upfront costs of helping people who may be at risk of becoming victimisers, and so it suffers an even greater cost when further crimes are committed. These costs include the cost of successfully bringing the victimiser before the court and then paying some $\$ 18,000$ a year to keep the offender in prison-estimated on the 2019/20 budget estimate of $\$ 28,922,266$ for the Bahamas Department of Correctional Services and a population of around 1,600 inmates at Fox Hill (Bahamas Government, 2019).

The link between rape and first sexual intercourse means that greater efforts should be made to encourage children to delay engaging in sexual intercourse. This suggests that education and support from home and church groups are important in providing appropriate messages which would result in children resisting peer-pressure to become sexually active. While becoming sexually active at an early age is of concern to healthcare providers, there are clear social behaviour concerns associated with early participation in sexual intercourse (O'Donnell et al., 2001). Further, those who did not solely have sex with their opposite sex, were at even greater risk of sexual abuse than "straight" persons. Again, given the stigma associated with non-heterosexual intercourse, this means that this subset of the population may be deprived protection by the law as they would be reluctant to report abuse by a member of the same sex.

In the general United States population, 8.2\% had experienced same sex sexual activity (Gates, 2011), so the results from this study (Table 10) are in line with this figure, bearing in mind that younger age groups are more likely to identify with a sexual orientation other than heterosexual (United Kingdom Office of National Statistics, 2020). In the United Kingdom, in the 16-24 age group, $13.8 \%$ of males and $12.6 \%$ of females (United Kingdom Office of National Statistics, 2020) identified as having a sexual orientation other than heterosexual, which suggests that the figures for college students in The Bahamas are aligned with the United Kingdom. This finding is of assistance when we note that heterosexual sexual intercourse is associated with a lower likelihood of harm compared with sexual encounters between persons of other sexual orientations. This becomes important in terms of these people obtaining support and assistance in failed relationships in a society which is regarded by some as homophobic (Martin-Mack, 2012).

With respect to fear of crime, the respondents' perceptions of fear of crime indicated that crimes against the person were of greatest concern. Rape/sexual abuse was of the greatest fears, particularly for females. This fear may arise from the belief that crimes are underreported. However, as demonstrated by Fielding (2019), society itself contributes to the fear of the unknown 
by not reporting all crimes, including rape or abuse, to the police. This lack of willingness to make victimisers accountable for their actions was again demonstrated in this study, as five of every six rape victims did not report the event, despite the detrimental effect rape/sexual abuse has on the victim's feeling of safety. This fear of rape reflects a lack of knowledge of participants as to who poses a real threat to them and how common rape is. This suggests that education initiatives for young people are not communicating information which can protect them from harm. The total lack of reporting with respect to male rape is of particular concern, as it gives the false impression that only females are victims of rape. It also prevents males from receiving the appropriate psychological support and enables victimisers to act with impunity. As with any sexual assault victim, this may leave them with longer-term issues following the assault (Dworkin et al., 2017).

As stated previously, consent is a key aspect in sexual encounters. Without consent, the same act, sexual intercourse, takes on a different character. Although many participants indicated that they gave clear consent, males were less likely to indicate this than females. We can conjecture that if the men are initiating the sexual encounter, they may feel that this is itself clear consent on their behalf, whereas if the women are responding to advances, they may be more likely to indicate if they wish to proceed with the encounter. The fact that many females stated that they consented to unwanted sexual intercourse indicates that they are responding unwillingly to pressure by another to participate in sexual intercourse. While this might not be classified as rape or abuse, it would appear to disrespect the wishes of the woman.

Although the Consent to Unwanted Sexual Intercourse Scale has not been used before in The Bahamas, it appears to shed light on why females can engage in unwanted sexual intercourse. The mean value from this study of the Consent to Unwanted Sexual Intercourse Scale, 59.1, was higher than the mean figures for Canadian female college students of 41.2 and 35.9 as reported by Humphreys \& Kennett (2011). This may suggest that Bahamian males are more likely than their Canadian counterparts to exercise coercive tactics to obtain sexual favours. Equally, however, it may also suggest that Bahamian female students are more likely to accede to coercive demands than female Canadian students, which points to an atmosphere of greater struggle between university males and females in The Bahamas than Canada. This conflict is consistent with university students in The Bahamas emerging from more violent backgrounds than their North American counterparts (Fielding et al., 2015) and gender-based violence in The Bahamas (Bethell-Bennett, 2016b).

Given this finding, it would be useful to learn more about why Bahamian women consent unwillingly to sexual intercourse. Given the apparent attachment needs of some respondents, the behaviour of our participants might be seen to align with those in other studies, such as Impett and Peplau (2002). Associated with the concern of consenting to unwanted sexual intercourse is the question of what constitutes consent in the Bahamian context. As in the United Kingdom, the lack of understanding concerning consent has implications for labeling acts as rape or not (Hills et al., 2020). While many aspects of consent are topics for further research in The Bahamian context, we can turn to Ferzan (2018) for a nuanced legal consideration of consent. She begins from the proposition that individuals possess a fundamental right to non-interference with their person or property, and defines coercion as taking place when conditions are created that threaten to make an individual worse off than they ought to be. In such situations, 
saying yes to unwanted interference with one's person should rightfully be termed assent rather than consent, as there is no voluntary ceding of the right to noninterference.

The majority of Bahamian citizens are descended from people who were brought to the country against their will, where they were deprived of their rights over their bodies, forced to labour for the benefit of others, and given no scope for selfdetermination. The very definition of a slave requires a removal of one's personhood and one's ability to exercise any control over one's circumstances. Under these conditions, violence and abuse are routine, even necessary. Curry and Ulentin's survey of incarceration in The Bahamas (2019) outlines the various measures taken by the state and the authorities to curtail the basic freedoms of the populace and to brutalise the incarcerated. It is conceivable, therefore, that survival strategies arose in response to those conditions that included an increased tolerance for coercion and a normalising of violent activity.

The reverse of these survival strategies might include a weakening of the understanding of what constitutes personal consent. Our findings suggest that individual respondents may not have a full understanding of their own agency, and certainly suggest an imperfect knowledge of their rights in situations of sexual pressure.

When applied to the Bahamian situation, in which citizens occupy a society that is built on coercion, occupation, and force, it is possible to argue that the normative goalposts have been moved. If one assumes the inherent legal right of individuals to be able to exist without having their property or persons touched without their consent, then the fact that the Caribbean is a region that is founded on the transgression of that right throughout history may not be incidental to the questions by our findings.

Further research in The Bahamas might usefully start to consider what are the accepted means by which consent is indicated, particularly by females, prior to sexual intercourse. Additional research could seek to establish the knowledge of residents about the long-term consequences of abuse and rape. Such information might allow more appropriate education of both minors and adults to help them protect themselves from harm.

If we consider the "five groups of potentially amenable risk factors [which] are important in rape perpetration: adverse childhood exposures; attachment and personality disorders; social learning and delinquency; gender inequitable masculinities; and substance abuse and firearms" (Jewkes, 2012, p. 1), we can appreciate that many students in our study would be expected to fall into one or more of these groups. Children are exposed to corporal punishment at both home and at school, and exhibit worry to the actions of the adults in their home (Fielding et al., 2016a), have difficulties with cognitive ability associated with violence in the home (Roth et al., 2020), experience ingrained gender inequalities (Bethel, 2003) and are aware of the ease with which illegal drugs can be obtained, (Bahamas Ministry of Health, 2019) as well as alcohol. Firearms, illegal or otherwise, are not uncommon in homes in The Bahamas and their presence is associated with behaviours of concern within the household and particularly of those who control the weapon (Hutcheson et al., 2016). These observations suggest that the risk factors identified by Jewkes (2012) may contribute to elevating the risk of rape within the Bahamian college population. Experiences of violence from an early age within and outside the home, may contribute to aggression in sexual relationships which are manifested by engaging in sexual intercourse without consent and of those who 
consent to unwanted sexual intercourse against their will, doing so out of fear.

The intergenerational aspects of violence within the home and the fear of interpersonal violence would suggest that the home environment is a key element in protecting people from sexual abuse. In a similar way that schools, religious organisations and society can influence the learning of gender- based attitudes (Fielding \& Ballance, 2019) it might be anticipated that the home is important in nurturing children so that they delay sexual activity. These findings are consistent with other studies, for example, O'Donnell et al. (2001), and so again suggest the need for support for children, particularly in homes where behaviours of concern occur.

\section{Acknowledgements}

The authors are grateful to students in a Spring 2019 Research Methods class at University of The Bahamas for their assistance in collecting the data. We are also grateful to the Counseling Department at University of The Bahamas for agreeing to support this project through student counselling if it was required. This project was approved by the Institutional Review Board of the University of The Bahamas. 


\section{References}

Aranha, S. B. (2016a). Bahamian-ness as an exclusive good: Attempting to change the constitution, 2002. International Journal of Bahamian Studies, 22, 1-18. https://doi.org/10.10.15362/ijbs.v22i0.25 8

Aranha, S. B. (2016b). Sexual abuse in the secret needing to be told. In W. Fielding, V. C. F. Ballance, \& I. G. Strachan, (Eds.), Violence in The Bahamas (pp. 8792). Media Enterprises.

Bahamas Government. (2019, May 29). Budget communication, 2019-2020. https://www.bahamas.gov.bs/wps/wcm/c onnect/8f7bfd5d-58b5-4b0e-b9cf95c588c3b1f6/Final+Budget+Communic ation.pdf?MOD=AJPERES

Bahamas Ministry of Health. (2018). Bahamas National Household Drug Prevalence survey report. http://www.cicad.oas.org/oid/pubs/Baha masNationalHouseholdDrugPrevalenceS urvey\%20Report-2018.pdf

Bahamas Ministry of Health. (2019). The Bahamas STEPS survey 2019:

Preliminary fact sheet. https://tinyurl.com/MOHBahamasSteps

Benjamin, L., \& LeGrand, C. (2012). Sound and fury: Newspaper coverage of the marital rape debate in New Providence. International Journal of Bahamian Studies, 18, 16-35. https://doi.org/ 10.15362/ijbs.v18i0.164

Bethel, N. (2003). Engendering The Bahamas: A gendered examination of Bahamian nation making, or national identity and gender in the Bahamian context. The College of The Bahamas
Research Journal, 12, 72-84. https://doi.org/10.15362/ijbs.v12i0.54

Bethell-Bennett, I. (2016a). In the shadows of violence and trauma: The state, postslavery trauma and neoliberal racial constructs and violence in The Bahamas. In W. J. Fielding, V. C. F. Ballance, \& I. G. Strachan, (Eds.), Violence in The Bahamas (pp. 1-21). Media Enterprises.

Bethell-Bennett, I. (2016b). Enlightened sexism, structural violence or the failure of representative democracy? The 2016 gender equality referendum. International Journal of Bahamian Studies, 22, 54-60. https://doi.org/10.0.60.2/ijbs.v22i0.272

Brooks, V. (2020). Greer's 'Bad Sex' and the future of consent. Sexuality and Culture, 24(3), 903-921. https://doi.org/10.1007/s12119-01909671-X

Cantor, D., Fisher, B., Chibnall, S., Harps, S., Townsend, R., Thomas, G., Lee, H., Krantz, V., Heribison, R., \& Madden, K. (2019). Report on the AAU campus climate survey on sexual assault and misconduct. Westat. https://ira.virginia.edu/sites/ias.virginia.e du/files/aau-uva-campus-climate-surveyreport-2019.pdf

Convention on the Elimination of all forms of Discrimination Against Women. (2018, November 14). Concluding observations on the sixth periodic report of the Bahamas. https://tbinternet.ohchr. org/_layouts/15/treatybodyexternal/Down load.aspx?symbolno=CEDAW $\% 2 \mathrm{fC} \% 2 \mathrm{f}$ $\mathrm{BHS} \% 2 \mathrm{fCO} \% 2 \mathrm{f} 6 \&$ Lang=en 
Cooper, A. (2019, April 5). Bringing awareness to child abuse. Freeport News. http://thefreeportnews.com/news/local/bri nging-awareness-to-child-abuse/

Curry, C., \& Ulentin, A. (2019). From punishment to rehabilitation: An historical overview of incarceration in The Bahamas. In W. J. Fielding, V. Ballance, P. Smith, A. Veyrat-Pontet, \& H. Sutton (Eds.), Our Prisoners: A collection of papers arising from a 2016 survey of inmates at The Bahamas Department of Correctional Services Facility at Fox Hill (pp. 3-20). InterAmerican Development Bank. https://doi.org/10.18235/0001593

Curry, G. (2016 June). Overview of violence against women: The Commonwealth of The Bahamas. https://hr.un.org/sites/ hr.un.org/files/Sabbatical\%20Report_VA W\%20in\%20the\%20Bahamas_GaynelCu rry_June\%202016_0.pdf

Deveaux, L., \& Rolle, G. (2016). The Focus on Youth prevention and education research programme. International Journal of Bahamian Studies, 22, 91-98. https://doi.org/10.15362/ijbs.v22i0.276

Dworkin, E., Bystrynski, J., Menon, S., \& Allen, N. (2017). Data for: Sexual assault victimization and psychopathology: A review and meta-analysis. Mendeley Data. https://doi.org/10.17632/m2tk4652bm.2

Feldhaus, K. M., Kozoil-McLain, J., Amsbury, H. L., \& Norton, I. M. (1997). Accuracy of 3 brief screening questions for detecting partner violence in the emergency department. JAMA, 277(17), 1357-61. https://doi.org/ 10.1001/jama.1997.03540410035027
Ferrarese, E. (2015). The political grammar of consent: Investigating a new gender order. Constellations, 22(3), 462-472. https://doi.org/10.1111/1467-8675.12172

Ferzan, K. K. (2018). Consent and coercion. Arizona State Law Journal, 50(4), 9511007. https://arizonastatelawjournal.org/wpcontent/uploads/2019/02/Ferzan-Pub.pdf

Fielding, W. J. (2019). Perceptions of crime and safety in The Bahamas. [Unpublished manuscript]. https://doi.org/10.13140/ RG.2.2.17410.43204

Fielding, W. J., \& Ballance, V. C. (2019). Learning gender-based attitudes in The Bahamas. International Journal of Bahamian Studies, 25, 1-15. https://doi.org/10.15362/ijbs.v25i0.339

Fielding, W. J., Ballance, V. C. F., \& Strachan, I. G., (Eds.). (2016a). Violence in The Bahamas. Media Enterprises.

Fielding, W. J., Ballance, V., Smith, P., Veyrat-Pontet, A., \& Sutton, H., (Eds.). (2019). Our prisoners: A collection of papers arising from a 2016 survey of inmates at The Bahamas Department of Correctional Services facility at Fox Hill. Inter-American Development Bank. https://doi.org/10.18235/0001593

Fielding, W. J., Johnson, K., Johnson, P., Minnis, J., Newbold, S., Pinder-Darling, A., Poitier-Albury, W., Riley W., \& Roberts, V. (2016b). Summary report on the Inter-American Drug Abuse Control Commission Caribbean University Interdisciplinary \& Integrated Drug Demand Reduction Project. https://www.researchgate.net/publication/ 313876700_Summary_report_on_the_Int er- 
American_Drug_Abuse_Control_Commi ssion_Caribbean_University_Interdiscipli nary_Integrated_Drug_Demand_Reducti on_Project_The_College_of_The_Baham as

Fielding, W. J., Risley-Curtiss, C., \& Cronin, T. W. (2015). A cross-cultural comparison of interpersonal violence in the lives of college students from two colleges from The Bahamas and United States of America. International Journal of Bahamian Studies, 21(1), 38-56. https://doi.org/10.15362/ijbs.v21i1.230

Five men convicted of sexual abuse rather than gang rape. (2019, October 31). Spain in English. https://www.spainenglish.com /2019/10/31/sexual-abuse-gang-rape/

Gates, G. J. (2011). How many people are lesbian, gay, bisexual, and transgender? The Williams Institute, UCLA School of Law. https://williamsinstitute.law.ucla. edu/wp-content/uploads/Gates-HowMany-People-LGBT-Apr-2011.pdf

Glasser, M., Kolvin, I., Campbell, D., Glasser, A., Leitch, I., \& Farrelly, S. (2001). Cycle of child sexual abuse: links between being a victim and becoming a perpetrator. The British Journal of Psychiatry, 179, 482-497. https://doi.org/10.1192/bjp.179.6.482

Gray, J. M. (2015). What constitutes a "reasonable belief" in consent to sex? A thematic analysis. Journal of Sexual Aggression, 21(3), 337-353.

https://www.doi.org/10.0.4.56/13552600. 2014.900122

Halcon, L., Blum, R. W., Beuhring, T., Pate, E., Campbell-Forrester, S., \& Venema, A. (2003). Adolescent health in the Caribbean: A regional portrait. American
Journal of Public Health, 93(11), 18511857.

https://ajph.aphapublications.org/doi/full/ 10.2105/AJPH.93.11.1851

Hartnell, N. (2020a, April 17). S\&P: Bahamas to shrink by $16 \%$. The Tribune. http://www.tribune242.com/news/2020/a pr/17/sp-bahamas-shrink-16/

Hartnell, N. (2020b, February 14). Beat OECD/EU to income tax. The Tribune. http://www.tribune242.com/news/2020/fe b/14/beat-oecdeu-to-income-tax/

Hills, P. J., Pleva, M., Seib, E., \& Cole, T. (2020, July 8). Understanding how university students use perceptions of consent, wantedness, and pleasure in labeling rape. Archives of Sexual

Behaviour. https://doi.org/ 10.1007/s10508-020-01772-1

Hovel, R. (2019, June 28). Israeli female judge says rape of men worse than rape of women. Haaretz. https://www.haaretz. com/israel-news/israeli-female-judgesays-rape-of-men-worse-than-rape-ofwomen-1.7418489

Humphreys, T. P., \& Kennett, D. (2011). Reason for consenting to unwanted sex scale. In T. D. Fisher, C. M. Davis, W. L. Yarber, \& S. L. Davis (Eds.), Handbook of sexuality-related measures. (3rd Ed., pp. 176-178). Routledge.

Husak, D., \& Thomas, G. (2001). Rapes without rapists: Consent and reasonable mistake. Philosophical Issues, 11, 86117. www.jstor.org/stable/3050597

Hutcheson, S. P., Brennen, S., Bethel, N., Allen Carroll, M., \& Fielding, W. J. (2016). Gun ownership in The Bahamas. In Fielding, W. J., Ballance, V. C. F., \& 
Strachan, I. G. (Eds.), Violence in The Bahamas (pp.135-158). Media Enterprises.

Impett, E. A., \& Peplau, L. A. (2002). Why some women consent to unwanted sex with a dating partner: Insights from attachment theory. Psychology of Women Quarterly, 26(4), 360-370.

https://doi.org/10.1111/1471-6402.t01-100075

Jewkes, R. (2012). Rape perpetration: A review. Sexual Violence Research Initiative. http://www.svri.org/sites /default/files/attachments/2016-0413/RapePerpetrationReview.pdf

Knowles, R. (2019, February 6). DeanPatterson: Bahamas facing rape epidemic. The Nassau Guardian. https://thenassauguardian.com/2019/02/0 6/dean-patterson-bahamas-facing-rapeepidemic/

Little, N. J. (2005). From no means no to only yes means yes: The rational results of an affirmative consent standard in rape law. Vanderbilt Law Review, 58(4), 1321-1364.

https://scholarship.law.vanderbilt.edu/vlr/ vol58/iss $4 / 5$

Man accused of rape claims he was molested as a child. (2011, February 07). https://www.bahamaslocal.com/newsitem /15144/Man_accused_of_rape_claimshe_ was_molested_as_a_child.html

Martin-Mack, C. (2012). Homophobic attitudes and stigma toward gay men and lesbians in the Caribbean: A systematic review of the literature. [Master's thesis, University of Pittsburgh]. http://dscholarship.pitt.edu/16552/1/MartinMackC_Thesis2012.pdf
Martos, J. (2014). Doors to the sacred: A historical introduction to sacraments in the Catholic Church. Liguori Press.

McKeever, N. (2019). Can a woman rape a man and why does it matter? Criminal Law and Philosophy, 13, 599-619. https://doi.org/10.1007/s11572-0189485-6

Metrik, J., Kahler, C. W., Reynolds, B., McGeary, J. E., Monti, Peter M., Haney, M., deWit, H., \& Rohsenow, D. J. (2012). Balanced placebo design with marijuana: Pharmacological and expectancy effects on impulsivity and risk taking. Psychopharmacology, 223, 489-499. https://doi.org/10.1007/s00213012-2740-y

Mills, C., \& Granoff, B. (1992). Date and acquaintance rape among a sample of college students. Social Work, 37(6), 504-509. https://doi.org/10.1093/sw/37.6.504

Nicolls, D., Russell-Smith, C., DeanPatterson, S., Deveaux-Stuart, L. D., Gibson-Mobley, I., Williams, E. J, Pinder-Darling, A., \& Fielding, W. J. (2014). Attitudes of high school students regarding intimate relationships and gender norms in New Providence, The Bahamas. International Journal of Bahamian Studies, 20(1), 38-51. https://doi.org/10.15362/ijbs.v20i1.225

O'Donnell, L., O'Donnell, C. R., \& Stueve, A. (2001). Early sexual initiation and subsequent sex-related risks among urban minority youth: The Reach for Health study. Family Planning Perspectives, 33(5), 268-275. https://doi.org/10.1363/3326801 
OECD Development Centre. (2019). Gender index: The Bahamas.

https://www.genderindex.org/wpcontent/uploads/files/datasheets/2019/BS. pdf

Plumridge, S. J., \& Fielding, W. J. (2009). Domestic violence in the homes of college students, New Providence, The Bahamas. The College of The Bahamas Research Journal 15, 45-55. https://doi.org/10.15362/ijbs.v15i0.116

Primoratz, I. (2001). Sexual morality: Is consent enough? Ethical Theory and Moral Practice, 4(3), 201-218. www.jstor.org/stable/27504193

Reid, S. D., Reddock, R., \& Nickenig, T. (2014). Breaking the silence of child sexual abuse in the Caribbean: A community-based action research intervention model. Journal of Child Sexual Abuse, 23, 256-277 https://doi.org/10.1080/10538712.2014.8 88118

Riccardi, P. (2010). Male rape: The silent victim and the gender of the listener. Primary Care Companion to the Journal of Clinical Psychiatry. 12(6). https://doi.org/10.4088/PCC.10100993wh i

Rolle: Marital rape is a private issue. (2017, December 20). The Nassau Guardian. https://thenassauguardian.com/2017/12/2 0/rolle-marital-rape-is-a-private-issue/

Roth, R. M., Abecassis, M., Isquith, P. K., \& Fielding, W. J. (2020, February 5-8). Corporal punishment in childhood is associated with self-rated executive functions in Bahamian college students [Poster presentation]. Meeting of the International Neuropsychological Society
Meeting, Denver, Colorado.

Rothman, E. F., Exner, D., \& Baughman, A. L. (2011). The prevalence of sexual assault against people who identify as gay, lesbian, or bisexual in the United States: A systematic review. Trauma, Violence, \& Abuse, 12(2), 55-66. https://doi.org/10.1177/15248380103907 07

Royal Bahamas Police Force. (2019). Crime statistics presented in 2019. Strategic Policy, Planning and Research Branch. http://www.royalbahamaspolice.org/Stati stics/stats2019.pdf

Russell, K. (2020, February 4). Marital rape not priority for PLP. The Tribune. http://www.tribune242.com/news/2020/fe b/05/marital-rape-not-priority-plp/

Scavella, N. (2020, January 14). Doctor accused of having child porn. The Tribune. http://www.tribune242.com /news/2020/jan/14/doctor-accusedhaving-child-porn/?news

Sexual Offences Act (1991) Bahamas (Ch. 99). http://laws.bahamas.gov.bs/cms/ images/LEGISLATION/PRINCIPAL/19 91/1991-0009/SexualOffencesAct_1.pdf

Sivakumaran, S. (2005) Male/male rape and the "taint" of homosexuality. Human Rights Quarterly, 27(4), 1274-1306 https://doi.org/10.1353/hrq.2005.0053

Strachan, I. (2013). I's man. Manhood in The Bahamas [Video]. YouTube. https://www.youtube.com/watch?v=Uun VToSyHMU

Sutton, H. (2016). Crime and violence in The Bahamas. Inter-American Development Bank. 
https://publications.iadb.org/publications/ english/document/Crime-and-Violencein-The-Bahamas-IDB-Series-on-Crimeand-Violence-in-the-Caribbean.pdf

Sutton, H. \& Ruprah, I. (Eds.). (2017). Restoring paradise in the Caribbean: Combatting violence with numbers. InterAmerican Development Bank. https://publications.iadb.org/publications/ english/document/Restoring-Paradise-inthe-Caribbean-Combatting-Violencewith-Numbers.pdf

United Kingdom Office of National Statistics. (2020). Sexual orientation, UK: 2018. Experimental statistics on sexual orientation in the UK in 2018 by region, sex, age, marital status, ethnicity and socio-economic classification. https://www.ons.gov.uk/peoplepopulation andcommunity/culturalidentity/sexuality/ bulletins/sexualidentityuk/2018\#sexualorientation-by-age
Virgil, K. (2013, December 5). Marco's Law is tabled in Parliament. The Tribune. http://www.tribune242.com/news/2013/d ec/05/marcos-law-is-tabled-inparliament/

Weller, R. A., \& Halikas, J. A. (1984). Marijuana use and sexual behavior, The Journal of Sex Research, 20(2), 186-193. https://www.doi.org/10.1080/002244984 09551216

Wilson, L. C., \& Scapa, A. (2015). Unacknowledged rape: The influences of child sexual abuse and personality traits. Journal of Child Sexual Abuse, 24, 975990. https://doi.org/10.1080/ $\underline{10538712.2015 .1082002}$

World Health Organization. (2002). World report on violence and health. https://www.who.int/violence_injury_pre vention/violence/global_campaign/en/full _en.pdf 